\title{
Essential minerals and inorganic contaminants (barium, cadmium, lithium, lead and vanadium) in dried bee pollen produced in Rio Grande do Sul State, Brazil
}

\author{
José Augusto Gasparotto SATTLER ${ }^{1 *}$, Adriane Alexandre Machado DE-MELOํ․ Kelly Souza do NASCIMENTO', \\ Illana Louise Pereira de MELO², Jorge MANCINI-FILHO², Aroni SATTLER ${ }^{3}$, \\ Ligia Bicudo de ALMEIDA-MURADIAN ${ }^{1}$
}

\begin{abstract}
Like other beehive products, such as honey, royal jelly and propolis, bee pollen has attracted great interest because of the health benefits it can provide when consumed. Bee pollen has high contents of sugars and proteins and a low content of lipids, it is also a rich source of vitamins and other bioactive compounds, which makes it an attractive micronutrient supplement. However, few studies have investigated its composition. Therefore, the aim of this study was to characterize the essential minerals and inorganic contaminants present in bee pollen produced at apiaries in Rio Grande do Sul State, Brazil. Inductively Coupled Plasma Optical Emission Spectrometry (ICP-OES) revealed the presence of 8 essential minerals (calcium, iron, copper, chromium, manganese, molybdenum, phosphorus and zinc) in the 5 analyzed samples; 6 of them were in sufficiently high amounts to meet dietary requirements. Of the 5 inorganic contaminants assessed (barium, cadmium, lithium, lead and vanadium), only cadmium was present at levels over the International Honey Commission's standards. All bee pollen samples showed a high content of the 8 essential minerals. Contamination usually results from the use of pesticides, fertilizers and other chemicals in agriculture; thus, monitoring of its levels must be included in bee pollen analysis.
\end{abstract}

Keywords: bee pollen; beehive products; essential minerals; inorganic contaminants.

Practical Application: Bee pollen: essential minerals and inorganic contaminants.

\section{Introduction}

Bee pollen is an agglomerate of pollen grains from different botanical sources, held together by bees' glandular secretion and a small amount of nectar (Brasil, 2001). It is known for its nutritional value and therapeutic effects and has attracted increasing interest in recent years because of the growing trend of diet supplementation with natural products (Funari et al., 2003; De-Melo et al., 2015).

Bee pollen is the greatest source of proteins, lipids, vitamins and minerals for bees. Its chemical and nutritional composition varies according to floral source and geographical origin, and other factors such as climatic conditions, soil type, processing and beekeeping activities (De-Melo et al., 2016; Sattler et al., 2015; Herbert \& Shimanuki, 1978).

A number of minerals such as potassium $(\mathrm{K})$, phosphorus $(\mathrm{P})$, magnesium $(\mathrm{Mg})$, calcium $(\mathrm{Ca})$, sodium $(\mathrm{Na})$, sulfur $(\mathrm{S})$, iron $(\mathrm{Fe})$, copper $(\mathrm{Cu})$, manganese $(\mathrm{Mn})$, zinc $(\mathrm{Zn})$, chromium $(\mathrm{Cr})$, nickel $(\mathrm{Ni})$, and selenium $(\mathrm{Se})$ have been found in bee pollen samples worldwide (Saavedra et al., 2007; Szczêsna, 2007; Kalbande et al., 2008). Minerals are essential for proper regulation of metabolic pathways and physiological processes. Their adequate intake is fundamental to maintain homeostasis, cell protection, functionality, and health, while their deficiency can trigger specific illnesses. Calcium, copper, iron, selenium, and zinc, for example, are indispensable because they play crucial roles in physiological processes and other numerous biological processes. Also, minerals are known to interact with genetic variants in a wide range of diseases (Stathopoulou et al., 2012).

Apart from essential minerals, bee pollen may also contain contaminants as it is exposed to different contamination sources in its environment (Bogdanov, 2006; Wiest et al., 2011). The indiscriminate use of pesticides on crops and the industrial contamination of soils, rivers and lakes introduce some heavy metals, harmful to living organisms, into agricultural ecosystems. A Brazilian study using 43 samples of dehydrated and granulated bee pollen from three southeastern states in Brazil concluded that Brazilian bee pollen is sensitive to environmental pollution and susceptible to contamination with inorganic elements and, for this reason, its production should be monitored to ensure safety. The researchers also suggested that it could be used as a bioindicator of contamination (Morgano et al., 2010). Inorganic contaminants may affect the metabolism of essential trace elements, such as copper, zinc, iron, manganese and selenium, by competing with them for binding in the biological system. This competition and the combination of ligands may have an 
adverse effect on the disposition and homeostasis of essential trace elements (Maihara et al., 2012; Lambert et al., 2012).

Data on mineral elements in Brazilian bee pollen are still scarce. Therefore, the purpose of this paper was to characterize the essential minerals and inorganic contaminants present in dried bee pollen produced in Rio Grande do Sul State, Brazil.

\section{Materials and methods}

\subsection{Materials}

Sampling and processing (dehydration) of the samples

Samples of unprocessed (in natura) bee pollen were collected at apiaries located in Rio Grande do Sul state, Brazil, between August and October, 2011. The beekeepers involved in this study were instructed to correct procedures of collection, use of specific food packaging and follow good production practices manual provided by Embrapa (Camargo et al., 2003). All samples were sent freeze to Laboratory of Food Analysis at University of São Paulo Table 1 shows the details of the 5 bee pollen samples used in this study, including sampling month, city, and geographical location of the apiaries (global positioning system - GPS). The purpose of using geographical indication (GI) in this study was to promote regional identity and inspire confidence among consumers and researchers as described in Sattler et al. (2015).

Samples were dried in a Fabbe-Primar ${ }^{\circledast}$ drying oven at $42^{\circ} \mathrm{C}$ for $20 \mathrm{~h}$ (processing time determined in preliminary studies), as recommended by Brazilian legislation (Brasil, 2001).

\subsection{Methods}

\section{Mineral content analysis}

\section{Sample preparation}

Before starting the test procedure all materials involved in the stages of analysis of this study were subjected to demineralization protocol (Nitric acid $20 \%$ for $24 \mathrm{~h}$ ) aiming at exclusion of possible contaminated materials.

Samples were first wet acid digested in count tubes containing nitric acid (65\%) and hydrogen peroxide on a digester block (Tecnal TE-040/25) at $150^{\circ} \mathrm{C}$ for 5 days. After complete digestion of organic matter, the mineral content was transferred into a $10 \mathrm{~mL}$ flask and the volume was made up with deionized water. A certified reference standard was also wet acid digested to ensure the sample preparation procedure was consistently applied.

\section{Analysis of minerals}

Analysis of the contents of calcium, iron, copper, manganese, zinc, barium, cadmium, chromium, lithium, molybdenum, phosphorus, lead and vanadium in the digested samples was performed using inductively Coupled Plasma Optical Emission
Spectrometry (ICP-OES), as described in Kostić et al. (2015). Samples were run in an iCAP 6500 Duo ICP spectrometer (Thermo Fisher Scientific, Cambridge, UK) equipped with a RACID 86 fourth-generation charge-injection device (CID) detector, providing simultaneous detection and axial and radial views. Contents were determined by comparison with analytical reference solutions.

\section{Data processing and statistical analysis}

Contents were expressed as means \pm standard deviation $(n=3)$. Inferential tests for normality (Shapiro-Wilks test) and for homogeneity of variances (Brown-Forsythe test) were run on Action v.2.5 software (Statcamp, Brazil). One-way ANOVA (homoscedastic data) or Welch-ANOVA (heteroscedastic data) was used to test differences among minerals from the 5 samples from Rio Grande do Sul State, Brazil, while Duncan's post-hoc multiple comparison test was used to compare means. P-values below 5\% were statistically significant (Granato et al., 2014).

\section{Results and discussion}

\subsection{Mineral composition}

The mineral composition results (calcium, iron, copper, chromium, manganese, molybdenum, phosphorus and zinc) for the 5 dehydrated bee-pollen samples are presented in Table 2. Statistical analysis showed significant difference in mineral content among samples, even among the 3 samples (B, C and D) collected at the same apiary. The levels of minerals may vary according to geographical and botanical origin of pollen grains (Szczêsna, 2007; Carpes et al., 2009; Morgano et al., 2012; Taha, 2015); therefore, pollen in samples collected at the same apiary may have been harvested from different flowers over the sampling period.

Bee pollen samples were richest in phosphorus $(\mathrm{P})$ (grand mean content - $480 \mathrm{mg} / 100 \mathrm{~g}$ ). ANVISA Resolution RDC N ${ }^{\circ} .54$ states a food is classified as a "high content food" if it is able to provide over $30 \%$ RDI (recommended daily intake) of a certain mineral per serving (100 g), and is classified as a "source food" if it is able to provide at least 15\% of RDI per serving (100 g) (Brasil, 2012). In this study, all 5 bee pollen samples fell into the "high content food" class and can be used as dietary sources of P by both men and women between 19 and 30 years (Brasil, 2005, 2012). Carpes et al. (2009) have reported P contents in samples collected in Rio Grande do Sul State (Brazil) ranging from 565 and $846 \mathrm{mg} / 100 \mathrm{~g}$. In a more comprehensive study using bee pollen samples from twelve Brazilian States, including Rio Grande do Sul State, Morgano et al. (2012) have observed P contents between 218 and $816 \mathrm{mg} / 100 \mathrm{~g}$. All samples in this study met the standard for P content (between 80 and $600 \mathrm{mg} / 100 \mathrm{~g}$ ) set by the International Honey Comission (IHC) (Campos et al., 2008).

Table 1. Details of the 5 unprocessed (in natura) bee pollen samples used in the study.

\begin{tabular}{ccccc}
\hline Samples & Apiaries & Sampling Month/Year & City & Location of Apiaries - GPS \\
\hline 1 & A & Aug/11 & Cruz Alta & $28^{\circ} 37^{\prime} 35.94^{\prime \prime} \mathrm{S} / 53^{\circ} 37^{\prime} 57.66^{\prime \prime} \mathrm{W}$ \\
$2-3-4$ & $\mathrm{~B}$ & Aug-Sept/11 & São Gabriel & $30^{\circ} 15^{\prime} 27.72^{\prime \prime} \mathrm{S} / 54^{\circ} 28^{\prime} 59.41^{\prime \prime} \mathrm{W}$ \\
5 & $\mathrm{C}$ & Oct/11 & São Gabriel & $30^{\circ} 27^{\prime} 13.09^{\prime \prime} \mathrm{S} / 54^{\circ} 22^{\prime} 08.51^{\prime \prime} \mathrm{W}$ \\
\hline
\end{tabular}


Table 2. Mineral composition of dehydrated bee-pollen samples from Rio Grande do Sul State, Brazil, and percentage (\%) of the recommended daily intake (RDI) of each mineral in one serving $(25 \mathrm{~g})$.

\begin{tabular}{|c|c|c|c|c|c|c|c|c|c|c|c|c|c|c|c|c|}
\hline \multirow[b]{2}{*}{ Samples } & \multirow[b]{2}{*}{$\mathrm{Ca}$} & \multirow[b]{2}{*}{$\begin{array}{c}\% \\
\text { DRI }^{\#}\end{array}$} & \multirow[b]{2}{*}{$\mathrm{Fe}$} & \multirow[b]{2}{*}{$\begin{array}{c}\% \\
\text { DRI }^{\#}\end{array}$} & \multirow[b]{2}{*}{$\mathrm{Cu}$} & \multirow[b]{2}{*}{$\begin{array}{c}\% \\
\text { DRI }^{\#}\end{array}$} & \multicolumn{4}{|c|}{ Mineral $(\mathbf{m g} / \mathbf{1 0 0 g})^{+}$} & \multirow[b]{2}{*}{ Mo } & \multirow[b]{2}{*}{$\begin{array}{c}\% \\
\text { DRI }^{\#}\end{array}$} & \multirow[b]{2}{*}{$\mathbf{P}$} & \multirow[b]{2}{*}{$\begin{array}{c}\% \\
\text { DRI }^{\#}\end{array}$} & \multirow[b]{2}{*}{$\mathrm{Zn}$} & \multirow[b]{2}{*}{$\begin{array}{c}\% \\
\text { DRI }^{\#}\end{array}$} \\
\hline & & & & & & & $\mathrm{Cr}$ & $\begin{array}{c}\% \\
\text { DRI }^{*}\end{array}$ & Mn & $\begin{array}{c}\% \\
\text { DRI }^{\#}\end{array}$ & & & & & & \\
\hline 1 & $64.3 \pm 0.2^{c}$ & 1.6 & $31.2 \pm 0.1^{\mathrm{a}}$ & $56^{*}$ & $1.31 \pm 0.0^{\mathrm{a}}$ & $36^{*}$ & $4.2 \pm 0.0^{\mathrm{a}}$ & $3021^{*}$ & $4.0 \pm 0.0^{\mathrm{b}}$ & $44^{*}$ & $0.46 \pm 0.0^{\mathrm{a}}$ & $258^{\star}$ & $443 \pm 4.4^{c}$ & $16^{* *}$ & $4.2 \pm 0.1^{\mathrm{b}}$ & 15 \\
\hline 2 & $71.7 \pm 0.1^{\mathrm{a}}$ & 1.8 & $5.8 \pm 0.0^{\mathrm{e}}$ & $10^{* *}$ & $0.76 \pm 0.0^{c}$ & $21^{* *}$ & $0.2 \pm 0.0^{b}$ & $132^{\star}$ & $2.8 \pm 0.0^{\mathrm{d}}$ & $30^{*}$ & $0.05 \pm 0.0^{\mathrm{b}}$ & $27^{\star *}$ & $495 \pm 1.0^{\mathrm{b}}$ & $18^{\star *}$ & $2.9 \pm 0.0^{\mathrm{d}}$ & 11 \\
\hline 3 & $72.2 \pm 0.2^{\mathrm{a}}$ & 1.8 & $9.9 \pm 0.0^{c}$ & $18^{*}$ & $0.75 \pm 0.0^{c}$ & $21^{* *}$ & $0.2 \pm 0.0^{b}$ & $154^{\star}$ & $3.2 \pm 0.0^{c}$ & $34^{*}$ & $0.04 \pm 0.0^{c}$ & $21^{\star *}$ & $493 \pm 1.7^{\mathrm{b}}$ & $18^{* *}$ & $3.1 \pm 0.0^{c}$ & 11 \\
\hline 4 & $67.9 \pm 0.3^{\mathrm{b}}$ & 1.7 & $8.1 \pm 0.1^{\mathrm{d}}$ & $14^{* *}$ & $0.68 \pm 0.0^{\mathrm{d}}$ & $19^{* *}$ & $0.2 \pm 0.0^{b}$ & $139^{*}$ & $4.0 \pm 0.0^{\mathrm{b}}$ & $43^{*}$ & $0.03 \pm 0.0^{c}$ & $18^{\star *}$ & $447 \pm 1.6^{c}$ & $16^{* *}$ & $2.9 \pm 0.0^{\mathrm{d}}$ & 10 \\
\hline 5 & $68.6 \pm 0.6^{\mathrm{b}}$ & 1.7 & $11.8 \pm 0.1^{\mathrm{b}}$ & $21^{*}$ & $0.83 \pm 0.0^{\mathrm{b}}$ & $23^{\star *}$ & $0.2 \pm 0.0^{b}$ & $143^{*}$ & $6.2 \pm 0.0^{\mathrm{a}}$ & $67^{*}$ & $0.02 \pm 0.0^{\mathrm{d}}$ & $11^{\star *}$ & $524 \pm 2.4^{\mathrm{a}}$ & $19^{* *}$ & $4.3 \pm 0.0^{\mathrm{a}}$ & 15 \\
\hline $\begin{array}{l}\text { Grand } \\
\text { mean }\end{array}$ & $68.9 \pm 0.3$ & - & $13.4 \pm 0.1$ & - & $0.87 \pm 0.0$ & - & $1.0 \pm 0.0$ & - & $4.0 \pm 0.0$ & - & $0.12 \pm 0.0$ & - & $480 \pm 2.2$ & - & $3.5 \pm 0.0$ & - \\
\hline
\end{tabular}

+All results are expressed as mean \pm standard deviation ( $\mathrm{n}=3$ ). \# Recommended daily intakes (RDI) for men/women between 19-30 years: Ca: 1000mg/day; Fe: 14mg/day; Cu: 900 $\mu \mathrm{g} /$ day;

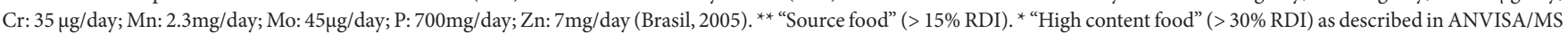
Resolution RDC No. 54 (Brasil, 2012). Means in the same column followed by different letters are significantly different.

The calcium (Ca) contents (64.3-72.2 mg/100 g) were consistent with those found by Carpes et al. (2009) for samples collected in Rio Grande do Sul State (54.0-214.9 mg/100 g); however, they were lower than the average content $(183.8 \mathrm{mg} / 100 \mathrm{~g})$ reported for samples from the same state analyzed by Morgano et al. (2012). Bee pollen samples from Korea, China, Poland and Romania showed an average Ca content of 43.0, 44.1, 76.2 and 202.0 mg/100 g, respectively (Szczêsna, 2007; Stanciu et al., 2011). Ca levels are variable and values between 20 and $300 \mathrm{mg} / 100 \mathrm{~g}$ are expected to be found in bee pollen (Campos et al., 2008).

The amounts of iron ( $\mathrm{Fe}$ ) observed in the present study (5.8-31.2 mg/100 g) were also consistent with those (2.8-20.3 mg/100 g) in Carpes et al. (2009) for nine bee pollen samples from Rio Grande do Sul State. Chinese samples showed Fe levels ranging from 7.5 to $20.8 \mathrm{mg} / 100 \mathrm{~g}$ (Yang et al., 2013). Higher Fe contents (between 33.8 and $56.2 \mathrm{mg} / 100 \mathrm{~g}$ ) have been reported in samples collected in Saudi Arabia; this may be due to the different botanical origin of the samples (Taha, 2015). With regard to Fe contents of bee pollen in this study, sample 1 can be classified as a "high content food" and samples 3 and 5 , both collected at the same apiary, can be classified "source foods” under ANVISA regulations (Brasil, 2005, 2012).

Manganese $(\mathrm{Mn})$ and copper $(\mathrm{Cu})$ levels (2.8-6.2 mg and $0.7-1.3 \mathrm{mg} / 100 \mathrm{~g}$ ) fell within the range of $1.9-4.3 \mathrm{mg}$ and 0.5-1.8 mg/100 g reported by Carpes et al. (2009) and Morgano et al. (2012), respectively, for Brazilian bee-pollen samples from Rio Grande do Sul. Szczêsna (2007), Yang et al. (2013) and Taha (2015) have reported similar results $(0.8-43$ and $0.3-2.5 \mathrm{mg} / 100 \mathrm{~g})$ in pollen samples from other countries. Each sample in this study can be classified as a "source food" of $\mathrm{Cu}$ and a "high content food" of Mn. Brazilian women are estimated to consume Mn at levels below the RDI (Panziera et al., 2011); therefore, the daily intake of bee pollen may contribute to preventing Mn deficiency.

Zinc $(\mathrm{Zn})$ contents were slightly lower (2.9-4.3 mg/100 g) than those found in samples collected in the same Brazilian state (3.7-8.2 mg/100 g) (Carpes et al., 2009) but were similar to those reported by Fuenmayor et al. (2014) for samples from Colombia (2.6-5.3 mg/100 g). Samples 1 and 5 are "source foods" of Zn under the ANVISA classification system (Brasil, 2005; Brasil, 2012).
The levels of chromium ( $\mathrm{Cr}$ ) and molybdenum (Mo) in the 5 simples ranged from 0.2 to $4.2 \mathrm{mg}$ and 0.02 to $0.46 \mathrm{mg} / 100 \mathrm{~g}$, respectively. To our knowledge, only one study about these minerals in bee pollen samples has been published; Yang et al. (2013) observed Mo levels between 0.01 and $0.04 \mathrm{mg} / 100 \mathrm{~g}$ in Chinese bee pollen but did not detect any $\mathrm{Cr}$ in the samples. A $25 \mathrm{~g}$ serving of bee pollen is enough to provide $100 \%$ of the RDI of Cr. Samples 2, 3 and 4 can be good sources of Mo and sample 1 can provide Mo levels twice as high as that of the RDI for men or women (19-30 years) (Brasil, 2005, 2012).

\subsection{Mineral contaminants}

The contents of inorganic contaminants (barium, cadmium, lithium, lead and vanadium) present in dehydrated bee pollen samples collected are shown in Table 3.

Inorganic contaminants were found in all 5 bee pollen samples analyzed. Barium $(\mathrm{Ba})$ was present at the highest levels (0.393-1.593 mg/100 g), comprising about 52\% of total mineral contaminants. Morgano et al. (2010) found an average Ba content of $0.541 \mathrm{mg} / 100 \mathrm{~g}$ in 43 samples of bee-pollen from three Brazilian States (São Paulo, Minas Gerais and Espírito Santo). Ba compounds have many industrial applications and their toxicity depends on their solubility in water or in the gastric juice (Berman, 1980).

To our knowledge, the presence of vanadium (V) and lithium (Li) in bee pollen samples has not been studied before. The essentiality of Vanadium for humans is still questioned, and there are not enough literature data to determine its nutritional index status. Some studies have reported that V can have a slowing effect on the metabolism of triacylglycerols and cholesterol. Although Vanadium is nutritionally important, it can be toxic if ingested at levels higher than $1.8 \mathrm{mg}$ per day. A $25 \mathrm{~g}$-serving of any bee pollen sample in this study, thus, can be a suitable source of Vanadium. The improper disposal of products containing Li can contaminate soil and water and eating contaminated food can cause serious damage to health (Floridia \& D’Agati, 2013).

Cadmium (Cd) levels, 0.0026-0.0244 mg/100 g, were lower than those found by Yang et al. (2013) for bee-pollen samples from China (0.015-0.049 mg/100 g). Lead $(\mathrm{Pb})$ contents $(0.012-0.018 \mathrm{mg} / 100 \mathrm{~g})$ fell within the range reported by Yang et al. 
Table 3. Contents of inorganic contaminants present in dehydrated bee pollen samples from Rio Grande do Sul State, Brazil.

\begin{tabular}{|c|c|c|c|c|c|}
\hline \multirow{2}{*}{ Samples } & \multicolumn{5}{|c|}{ Mineral $(\mathbf{m g} / \mathbf{1 0 0 g})^{+}$} \\
\hline & $\mathbf{B a}$ & Cd & $\mathrm{Li}$ & $\mathrm{Pb}$ & $\mathrm{V}$ \\
\hline 1 & $0.660 \pm 0.006^{b}$ & $0.0026 \pm 0.0002^{\mathrm{d}}$ & $0.223 \pm 0.001^{\mathrm{b}}$ & $0.018 \pm 0.001^{\mathrm{a}}$ & $0.399 \pm 0.004$ \\
\hline 2 & $0.393 \pm 0.002^{\mathrm{e}}$ & $0.0029 \pm 0.0001^{\mathrm{d}}$ & $0.191 \pm 0.002^{\mathrm{e}}$ & $0.012 \pm 0.002^{\mathrm{b}}$ & $0.489 \pm 0.003^{a}$ \\
\hline 3 & $0.506 \pm 0.002^{\mathrm{d}}$ & $0.0060 \pm 0.0000^{c}$ & $0.215 \pm 0.002^{c}$ & $0.015 \pm 0.001^{\mathrm{ab}}$ & $0.489 \pm 0.004^{a}$ \\
\hline 4 & $0.570 \pm 0.008^{c}$ & $0.0098 \pm 0.0001^{\mathrm{b}}$ & $0.200 \pm 0.002^{\mathrm{d}}$ & $0.012 \pm 0.002^{\mathrm{b}}$ & $0.423 \pm 0.003^{b}$ \\
\hline 5 & $1.593 \pm 0.017^{\mathrm{a}}$ & $0.0244 \pm 0.0003^{\mathrm{a}}$ & $0.235 \pm 0.002^{\mathrm{a}}$ & $0.017 \pm 0.001^{\mathrm{a}}$ & $0.416 \pm 0.004$ \\
\hline Grand mean & $0.744 \pm 0.007$ & $0.0091 \pm 0.0001$ & $0.213 \pm 0.002$ & $0.015 \pm 0.001$ & $0.443 \pm 0.003$ \\
\hline
\end{tabular}

+ All results are expressed as mean \pm standard deviation $(n=3)$. Means in the same column followed by different letters are significantly different.

(2013) (0.005-0.137 mg/100 g) and were similar to the average content value observed by Morgano et al. (2010) for Brazilian samples $(0.012 \mathrm{mg} / 100 \mathrm{~g})$. Samples 3,4 and 5 failed to meet the standards for $\mathrm{Cd}$ and $\mathrm{Pb}$ levels in bee pollen $(0.003 \mathrm{mg}$ and $0.05 \mathrm{mg} / 100 \mathrm{~g}$, respectively) proposed by Campos et al. (2008). Since cadmium (Cd) is an element used in a number of industrial processes and can be found in phosphate-based fertilizers, it may contaminate water supplies and/or pollen sources for bees.

\section{Conclusion}

Overall, all the samples in this study showed a high content of the essential minerals assessed, especially iron, chromium and manganese. Two samples ( 1 and 2), in particular, from two different locations in Rio Grande do Sul State (Brazil), were found to be suitable sources of these minerals. Because contamination can occur as a result of improper use of pesticides, fertilizers and other chemicals in agriculture, careful handling and frequent monitoring are essential to ensure food safety.

\section{Acknowledgements}

The authors would like to thank CAPES (Coordination of Improvement of Higher Education Personnel) for the scholarship granted (PROEX/CAPES - J.A.G Sattler) and all the beekeepers who participated in this study.

\section{References}

Berman, E. (1980). Toxic metals and their analysis. London: Heyden \& Sons.

Bogdanov, S. (2006). Contaminants of bee products. Apidologie, 37(1), 1-18. http://dx.doi.org/10.1051/apido:2005043.

Brasil. (2001, 23 January). Brazilian Legislation of 19 January 2001 implementing Normative Instruction 3/MAPA/Brazil that approved the Technical Regulations of Identity and Quality of bee venom, beeswax, royal jelly, lyophilized royal jelly, bee pollen, propolis and propolis extract. Union Official Diary, section 1.

Brasil. (2005, September 23). A Diretoria Colegiada da Agência Nacional de Vigilância Sanitária aprova o Regulamento Técnico sobre a Ingestão Diária Recomendada (IDR) de Proteína, Vitaminas e Minerais (Resolução RDC n 269, de 22 de setembro de 2005). Diário Oficial da União, seção 1, n. 184.

Brasil. (2012, November 13). A Diretoria Colegiada da Agência Nacional de Vigilância Sanitária aprova o Regulamento sobre Informação Nutricional Complementar (Resolução RDC nº 54, de 12 de novembro de 2012). Diário Oficial da União, seção 1, n. 219.
Camargo, R. C. R., Rêgo, J. G. S., Lopes, M. T. R., \& Pereira, F. M. (2003) Boas práticas na produção e beneficiamento de pólen apícola desidratado. Teresina: Embrapa Meio-Norte.

Campos, M. G. R., Bogdanov, S., Almeida-Muradian, L. B., Szczesna, T., Mancebo, Y., Frigerio, C., \& Ferreira, F. (2008). Pollen composition and standardization of analytical methods. Journal of Apicultural Research and Bee World, 47(2), 156-163. http://dx.doi.org/10.3896/ IBRA.1.47.2.12.

Carpes, S. T., Mourão, G. B., Alencar, S. M., \& Masson, M. L. (2009). Chemical Composition and free radical scavenging activity of Apis mellifera bee pollen from Southern Brazil. Brazilian Journal of Food Technology, 12(3), 220-229. http://dx.doi.org/10.4260/ BJFT2009800900016.

De-Melo, A. A. M., Estevinho, M. L. M. F., \& Almeida-Muradian, L. B. (2015). A diagnosis of the microbiological quality of dehydrated bee-pollen produced in Brazil. Letters in Applied Microbiology, 61(5), 477-483. http://dx.doi.org/10.1111/lam.12480. PMid:26280091.

De-Melo, A. A. M., Estevinho, M. L. M. F., Sattler, J. A. G., Souza, B. R., Freitas, A. S., Barth, O. M., \& Almeida-Muradian, L. B. (2016). Effect of processing conditions on characteristics of dehydrated bee-pollen and correlation between quality parameters. LWT - Food Science and Technology, 65, 808-815. http://dx.doi.org/10.1016/j. lwt.2015.09.014.

Floridia, A., \& D’Agati, M. G. (2013). Lithium (Li). In M. Ferrante, G. O. Conti, Z. Rasic-Milutinovic \& D. Jovanovic. Health effects of metals and related substances in drinking water (pp. 63-67). London: IWA Publishing.

Fuenmayor, C., Zuluaga, C., Díaz, C., Quicazán, M., Cosio, M., \& Mannino, S. (2014). Evaluation of the physicochemical and functional properties of Colombian bee pollen. Revista MVZ Córdoba, 19(1), 4003-4014.

Funari, S. R. C., Rocha, H. C., Sforcin, J. M., Filho, H. G., Curi, P. R., Gomes Dierckx, S. M. S., Funari, A. R. M., \& Orsi, R. O. (2003). Composições bromatológica e mineral de pólen coletado por abelhas africanizadas (Apis mellifera L.) em Botucatu, Estado de São Paulo. Archivos Latinoamericanos de Producción Animal, 11, 88-93.

Granato, D., de Araújo Calado, V. M., \& Jarvis, B. (2014). Observations on the use of statistical methods in Food Science and Technology. Food Research International, 55, 137-149. http://dx.doi.org/10.1016/j. foodres.2013.10.024.

Herbert, E. W. Jr, \& Shimanuki, H. (1978). Chemical composition and nutritive value of bee-collected and bee-stored pollen. Apidology, 9(1), 33-40. http://dx.doi.org/10.1051/apido:19780103.

Kalbande, D. M., Dhadse, S. N., Chaudhari, P. R., \& Wate, S. R. (2008). Biomonitoring of heavy metals by pollen in urban environment. Environmental Monitoring and Assessment, 138(1-3), 233-238. http:// dx.doi.org/10.1007/s10661-007-9793-0. PMid:17593535. 
Kostić, A. Ž., Pešić, M. B., Mosić, M. D., Dojčinović, B. P., Natić, M. M., \& Trifković, J. Đ. (2015). Mineral content of bee pollen from Serbia. Arhiv za Higijenu Rada i Toksikologiju, 66(4), 251-258. http://dx.doi. org/10.1515/aiht-2015-66-2630. PMid:26751856.

Lambert, O., Piroux, M., Puyo, S., Thorin, C., Larhantec, M., Delbac, F., \& Pouliquen, H. (2012). Bees, honey and pollen as sentinels for lead environmental contamination. Environmental Pollution, 170, 254-259. http://dx.doi.org/10.1016/j.envpol.2012.07.012. PMid:22842054.

Maihara, V. A., Fávaro, D. I. T., \& Barbosa, F. (2012). Elementos tóxicos. In S. M. F. Cozzolino. Biodisponibilidade de nutrientes (4th ed., pp. 845-877). Barueri: Manole.

Morgano, M. A., Martins, M. C. T., Rabonato, L. C., Milani, R. F., Yotsuyanagi, K., \& Rodriguez-Amaya, D. B. A. (2012). A comprehensive investigation of the mineral composition of brazilian bee pollen: geographic and seasonal variations and contribution to human diet. Journal of the Brazilian Chemical Society, 23(4), 727-736. http:// dx.doi.org/10.1590/S0103-50532012000400019.

Morgano, M. A., Martins, M. C. T., Rabonato, L. C., Milani, R. F., Yotsuyanagi, K., \& Rodriguez-Amaya, D. B. (2010). Inorganic contaminants in bee pollen from southeastern Brazil. Journal of Agricultural and Food Chemistry, 58(11), 6876-6883. http://dx.doi. org/10.1021/jf100433p. PMid:20450185.

Panziera, F. B., Dorneles, M. M., Durgante, P. C., \& Silva, V. L. (2011). Avaliação da ingestão de minerais antioxidantes em idosos. Revista Brasileira de Geriatria e Gerontologia, 14(1), 49-58. http://dx.doi. org/10.1590/S1809-98232011000100006.

Saavedra, A. R., Di Bernardo, M. L., Rondon, C., Gutiérrez, L., Saavedra, O., González, I., \& Vit, P. (2007). Determinación de plomo en polen apícola de Brassica napus L. del Páramo de Misintá, estado Mérida, Venezuela. Revista del Instituto Nacional de Higiene Rafael Rangel, 38, 6-10.
Sattler, J. A. G., Melo, I. L. P., Granato, D., Araújo, E., Freitas, A. S., Barth, O. M., Sattler, A., \& Almeida-Muradian, L. B. (2015). Impact of origin on bioactive compounds and nutritional composition of bee pollen from southern Brazil. Food Research International, 77, 82-91. http://dx.doi.org/10.1016/j.foodres.2015.09.013.

Stanciu, O. G., Marghitas, L. A., Dezmirean, D., \& Campos, M. G. (2011). A comparison between the mineral content of flower and honeybee collected pollen of selected plant origin (Helianthus annuus L. and Salix sp.). Romanian Biotechnological Letters, 16(4), 6291-6296.

Stathopoulou, M. G., Kanoni, S., Papanikolaou, G., Antonopoulou, S., Nomikos, T., \& Dedoussis, G. (2012). Mineral Intake. Progress in Molecular Biology and Translational Science, 108, 201-236. http:// dx.doi.org/10.1016/B978-0-12-398397-8.00009-5. PMid:22656379.

Szczêsna, T. (2007). Concentration of selected elements in honeybeecollected pollen. The Journal of Agricultural Science, 51, 5-13.

Taha, E. A. (2015). Chemical composition and amounts of mineral elements in honeybee-collected pollen in relation to botanical origin. The Journal of Agricultural Science, 59(1), 75-81. http:// dx.doi.org/10.1515/jas-2015-0008.

Wiest, L., Bulete, A., Giroud, B., Fratta, C., Amic, S., Lambert, O., Pouliquen, H., \& Arnaudguilhem, C. (2011). Multi-residue analysis of 80 environmental contaminants in honeys, honeybees and pollens by one extraction procedure followed by liquid and gas chromatography coupled with mass spectrometric detection. Journal of Chromatography A, 1218(34), 5743-5756. http://dx.doi. org/10.1016/j.chroma.2011.06.079. PMid:21783197.

Yang, K., Wu, D., Ye, X., Liu, D., Chen, J., \& Sun, P. (2013). Characterization of chemical composition of bee pollen in China. Journal of Agricultural and Food Chemistry, 61(3), 708-718. http://dx.doi.org/10.1021/ jf304056b. PMid:23265625. 